\title{
Evaluation of the fructosamine test for the measurement of plasma protein glycation
}

\author{
R. Flückiger, T. Woodtli and W. Berger \\ Departments of Research and Internal Medicine, University Clinics, Kantonsspital, Basel, Switzerland
}

Summary. Repeated estimation of plasma protein glycation by the fructosamine assay gave more variable results than expected from analytical variablility (coefficient of variation approximately $2 \%$ ). Fructosamine results obtained on plasma samples drawn at different times of the day differed by up to $1 \mathrm{mmol} / 1$, corresponding to a coefficient of variation of greater than $10 \%$. As a consequence, the information concerning averaged glycaemia of a fructosamine determination is subject to an uncertainty of $7.8 \mathrm{mmol} / 1$. Fructosamine con- centrations were linearly related to the protein concentration. Correction for the protein concentration decreased this variability; however, factors other than protein concentration, such as lipid content, also influence results of fructosamine determinations.

Key words: Non-enzymatic protein glycosylation, protein glycation, quantitation, reductive properties, fructosamine test.
Non-enzymatic glycosylation of proteins occurs in proportion to the prevailing concentration of glucose. The extent of glycation of proteins in blood therefore reflects the blood glucose concentration averaged over their life span. Because of the long and rather constant 120-day life span of the erythrocyte, glycation of haemoglobin has proved a useful parameter for assessing long-term glycaemia in diabetes [1].

Determination of the extent of glycation of the plasma proteins or of albumin (which has a half life in the circulation of 19 days) could provide a clinically useful objective measure of intermediate-term glycaemia whenever more recent changes in glycaemia have to be documented; i. e. during institution of a new therapeutic regimen or during pregnancy.

Quantitation of serum or plasma protein glycation by either the thiobarbituric acid colorimetric technique [2] or the furosine assay [3] are too time-consuming to be useful for routine measurements. To render the quantitation of serum or plasma protein glycation easier, boronate affinity chromatography [4] and the fructosamine test [5] have been recently introduced.

The fructosamine test relies on the reductive properties, under alkaline conditions, of the ketoamine in glycated proteins. Reductive ring-opening of the redox-dye nitroblue tetrazolium chloride to its formazan forms [6] causes an absorption change in the visible spectrum which is proportional to the concentration of glycated proteins in the sample.

We have evaluated the fructosamine assay in some detail because this test is amenable to automation and may become diagnostically important.

\section{Subjects and methods}

\section{Patients and controls}

Blood was obtained from 9 Type 1 (insulin-dependent) diabetic patients treated at the outpatient clinics of the Kantonsspital Basel, 50 normoglycaemic blood donors, and 13 women pregnant for 20 to 40 weeks with no signs of glucose intolerance as assessed by random blood glucose determinations and $\mathrm{HbA}_{1 \mathrm{c}}$.

Blood samples were collected from 4 Type 1 diabetic patients at hourly intervals over $48 \mathrm{~h}$ from an indwelling Venflon $18 \mathrm{G}$ catheter (Viggo $\mathrm{AB}$, Helsingborg, Sweden). These patients were asked to maintain their normal physical, eating and sleep habits during the study. When awake, blood samples were withdrawn while the patients were in a sitting position. Overnight profiles were determined in 2 normoglycaemic volunteers.

\section{Methods}

Blood was collected into plain Vacutainers (Becton Dickinson, Parsippany, NJ, USA) for serum, and in EDTA- or heparin-Vacutainers for plasma. Samples were kept frozen at $-20{ }^{\circ} \mathrm{C}$ until they were analysed. The fructosamine assay was performed on the Cobas Bio centrifugal analyser [7] utilising commercial reagents (F.HoffmannLaRoche, Basel, Switzerland). The commercial reagent consisted of $0.25 \mathrm{mmol} / 1$ nitroblue tetrazolium chloride (NBT) in $0.1 \mathrm{~mol} / 1 \mathrm{car}$ bonate buffer, $\mathrm{pH} 10.35$. Reduction of NBT was followed at $530 \mathrm{~nm}$ at $37{ }^{\circ} \mathrm{C}$, and the difference between the optical density at 10 and $15 \mathrm{~min}$ was calculated. Standardisation of the assay was performed with a glycated albumin standard containing $2.76 \mathrm{mmol} / \mathrm{l}$ fructosamine. The absorbance difference obtained with the glycated albumin standard was approximately 0.06 .

In the manual procedure, $100 \mu$ of plasma were mixed with $1 \mathrm{ml}$ reagent, prewarmed to $37{ }^{\circ} \mathrm{C}$, and the reaction mixture was transfered into a thermostated cuvette. The absorbance change was monitored at $530 \mathrm{~nm}$, and a spectrum was recorded at the end of the 15 min incubation.

Protein determinations were performed on the Cobas Bio analyser using the protein test kit containing a modified Biuret reagent [8] 


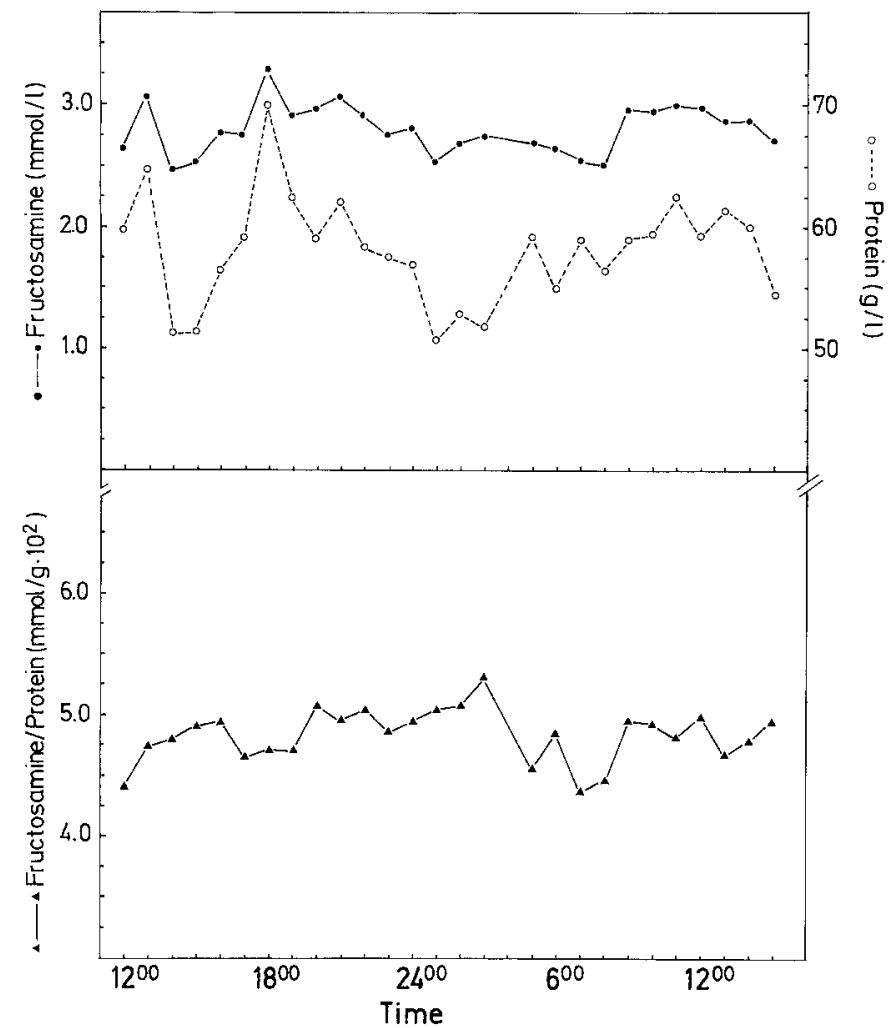

Fig. 1. Variation of fructosamine and protein concentration. Upper panel: fructosamine values not corrected for protein; lower panel: fructosamine values corrected for protein

Table 1. Fructosamine concentration with and without correction for protein concentration

\begin{tabular}{|c|c|c|c|c|}
\hline Subjects & $\begin{array}{l}\text { Normo- } \\
\text { glycaemic } \\
\text { non-preg- } \\
\text { nant }\end{array}$ & $\begin{array}{l}\text { Normo- } \\
\text { glycaemic } \\
\text { pregnant }\end{array}$ & $\begin{array}{l}\text { Diabetic, } \\
\text { patient B }\end{array}$ & $\begin{array}{l}\text { Diabetic, } \\
\text { patient A }\end{array}$ \\
\hline$n$ & 50 & 13 & $45^{\mathrm{a}}$ & $45^{a}$ \\
\hline $\mathrm{HbA}_{1 \mathrm{c}}(\%)$ & n.d. & 3.8 & 6 & 10.5 \\
\hline \multicolumn{5}{|l|}{$\begin{array}{l}\text { Without protein } \\
\text { correction }\end{array}$} \\
\hline Mean (mmol/1) & 2.07 & 1.96 & 3.30 & 4.05 \\
\hline SD & 0.15 & 0.13 & 0.42 & 0.38 \\
\hline range & $1.8-2.39$ & $1.79-2.21$ & $2.76-3.75$ & $3.35-4.74$ \\
\hline c.v. & 7.2 & 6.6 & 12.7 & 9.4 \\
\hline \multicolumn{5}{|c|}{$\begin{array}{l}\text { Values corrected } \\
\text { for protein }\end{array}$} \\
\hline $\begin{array}{l}\text { Mean } \\
\left(\mathrm{mmol} / \mathrm{g} \times 10^{2}\right)\end{array}$ & 3.12 & 3.07 & 5.40 & 6.94 \\
\hline SD & 0.16 & 0.20 & 0.49 & 0.29 \\
\hline range & $2.66-3.38$ & $2.61-3.32$ & $4.24-6.34$ & $6.41-7.58$ \\
\hline c.v. & 5.1 & 6.6 & 9.1 & 4.2 \\
\hline
\end{tabular}

a Number of samples obtained from each subject at different times c. v.: coefficient of variation; n.d.: not determined. $\mathrm{HbA}_{1 \mathrm{c}}$ in control subjects $4.9 \%$ (SD $0.4 \%)$

To correct for protein, fructosamine results $(\mathrm{mmol} / \mathrm{l})$ were divided by the protein concentration $(\mathrm{g} / \mathrm{l})$.

$\mathrm{HbA}_{1 \mathrm{c}}$ was determined by cation exchange chromatography as previously described [9].

\section{Statistical analysis}

Least-squares regression was used for line fitting.

\section{Results}

\section{Comparison between serum and plasma values}

Fructosamine concentrations obtained in the presence of either EDTA or heparin as anticoagulant were comparable. Plasma fructosamine concentrations were on the average $0.1 \mathrm{mmol} / 1$ lower than serum fructosamine values. For convenience all other fructosamine determinations were performed on plasma only.

\section{Analytical variability}

The intra-assay precision of the automated fructosamine test was estimated from duplicate analyses. The coefficient of variation was $1.8 \%$. Interassay variability was $3.0 \%$.

\section{Intrapatient variability}

The variability of fructosamine determinations on multiple samples obtained within $48 \mathrm{~h}$ in Type 1 diabetic patients exceeded analytical variability considerably (Table 1). Figure 1 shows the diurnal variation of fructosamine and protein concentrations in a diabetic patient. Fructosamine $(y)$ and protein concentration $(x)$ were linearly related $(y=0.037 x+0.65 ; n=27$; $r=0.82$ ). The regression lines computed from results on hourly plasma samples obtained over $48 \mathrm{~h}$ from 2 diabetic patients, one in poor and the other in satisfactory metabolic control, are shown in Figure $2 \mathrm{~A}$ and B.

The dependence of fructosamine and protein concentration was also determined in 2 non-diabetic individuals from which six plasma samples with variable protein concentration were obtained (data not shown).

\section{Interpatient variability}

The regression lines computed for these $6 \mathrm{~h}$ profiles were comparable to the regression line obtained by correlating values from different individuals (Fig. 2, C). In non-diabetic pregnant women direct fructosamine values were $5 \%$ lower than those of non-pregnant control subjects.

\section{Correction for protein concentration}

After a correction for the protein concentration of fructosamine values, the overlapping of the direct fructosamine values of the diabetic patient $\mathrm{A}$ in poor glycaemic control and of patient $B$ in satisfactory control disappeared (Table 1). Correcting fructosamine values for protein concentration reduced the variability in samples drawn at different times of the day by approximately one third, i.e. from $7.1 \%$ to $4.5 \%$ for the data shown in Figure 1. Correcting fructosamine values from normoglycaemic persons caused some narrowing in the distribution of values (Fig. 3).

During normal pregnancy direct fructosamine values and protein concentrations were decreased by $5 \%$; 


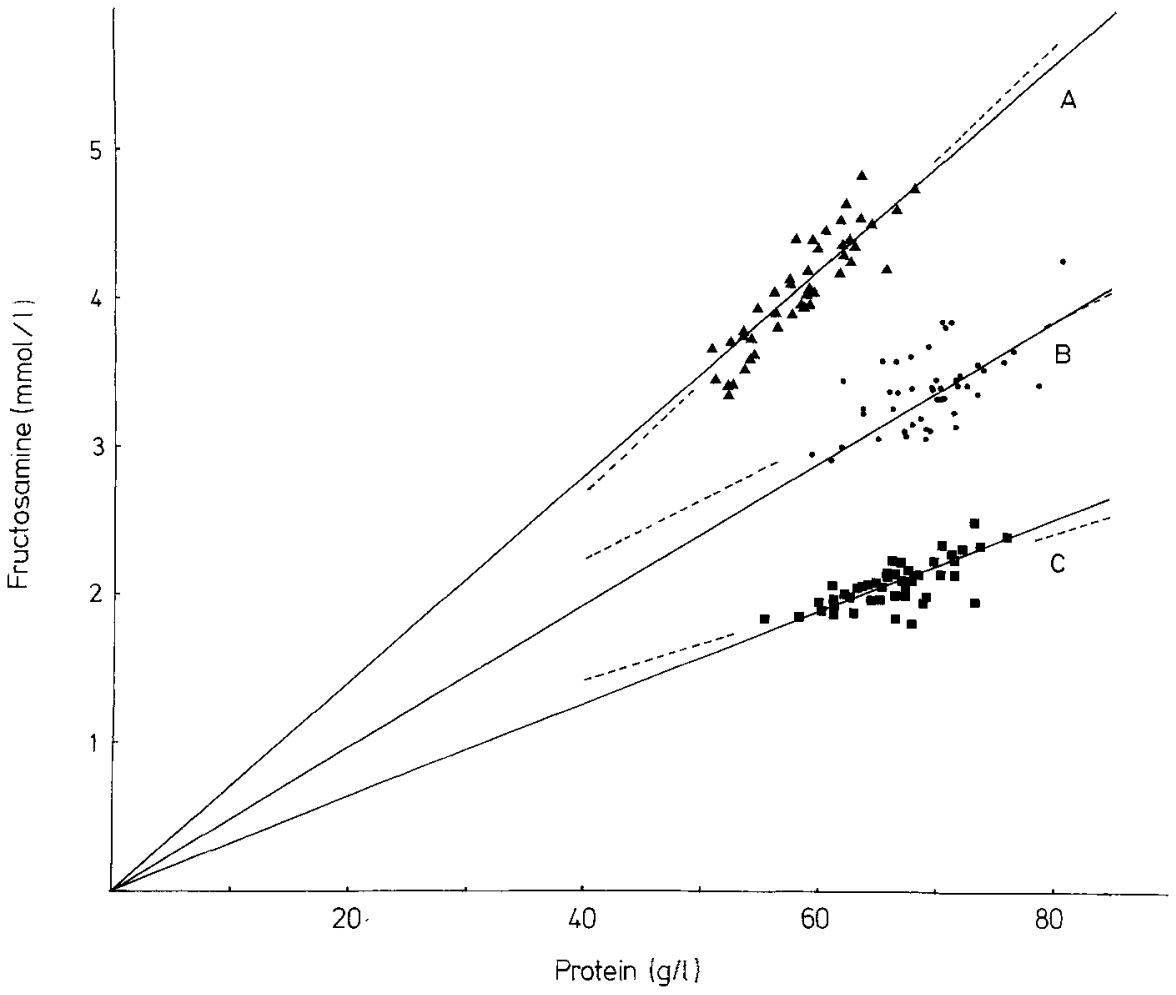

Abb. 2. Relationship between fructosamine and protein concentration. A: patient in poor glycaemic control; $\mathrm{y}=0.076 x-0.39(r=0.89)$. B: patient in satisfactory stable glycaemic control; $y=0.037 x-0.84(r=0.59)$. C: values from normoglycaemic blood donors; $y=0.025 x-0.40(r=0.70)$.

Solid line indicates the line with no $y$-intercept: the broken line shows the regression line computed by least-square regression analysis

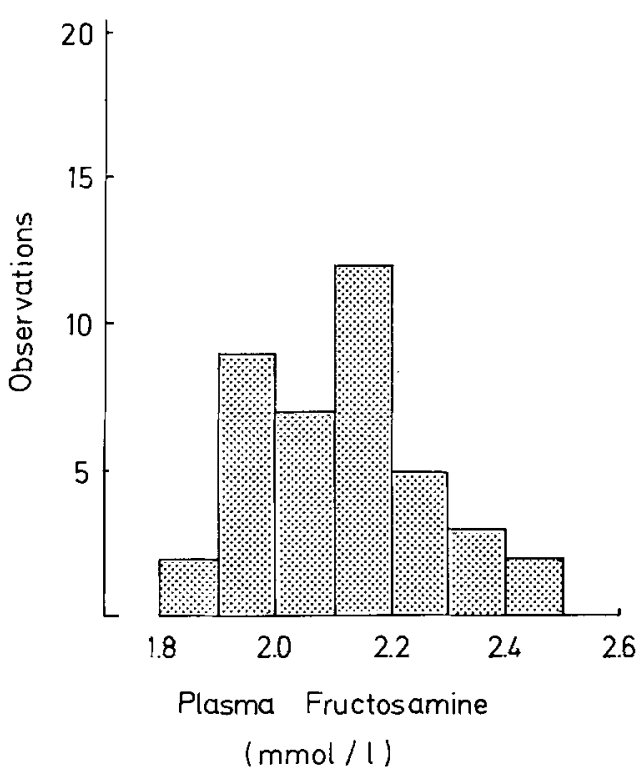

frucosamine concentrations corrected for protein were comparable to those of normoglycaemic controls (Table 1).

\section{Influence of lipid content}

Inspection of the absorbance spectrum of the color developed in the fructosamine test showed the presence of a shoulder at approximately $600 \mathrm{~nm}$. This shoulder was much less pronounced in the glycated albumin standard than in plasma samples. Delipidation of plasma with Aerosil treatment [10] largely, but not completely, decreased the absorbance in this wavelength range. Exposure of delipidated plasma samples to palmitate caused this shoulder to reappear. Similar exposure to palmitate of the glycated albumin standard dissolved in water did not cause the absorbance at $600 \mathrm{~nm}$ to increase.

The effect of delipidation was evaluated on selected patient samples. Delipidation increased the relative colour yield. While the protein content was decreased by the delipidation procedure by $20 \%$, the colour obtained was only $10-15 \%$ lower in delipidated samples. The variability of the fructosamine concentration determined in multiple samples from the same patient was comparable with delipidated and untreated samples. 


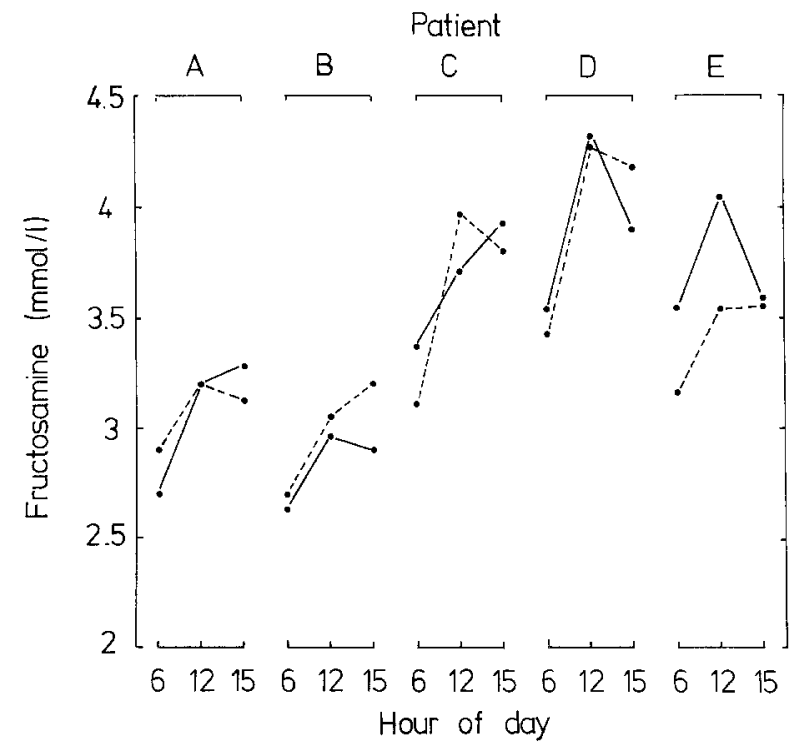

Fig.4. Repeated fructosamine determinations at specified times. Determinations were performed on successive days, $O$------ $O 1$ st day; 2nd day, fasting before insulin, before lunch and in the afternoon.

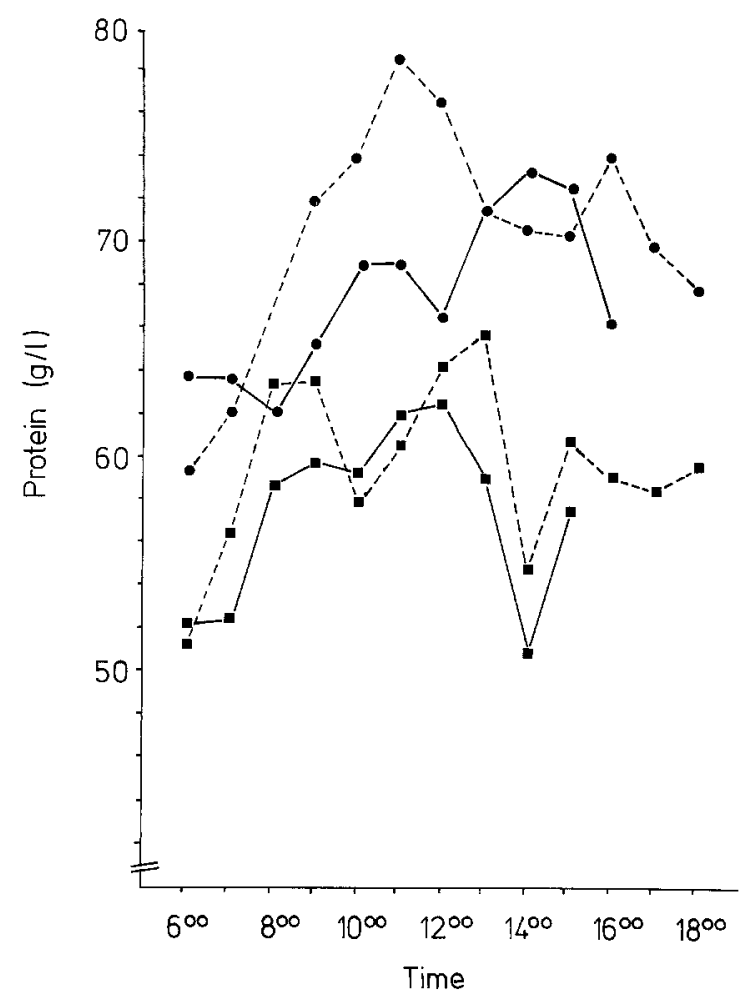

Fig.5. Diurnal variation of the plasma protein concentration. Determined in 2 diabetic patients on 2 successive days. patient 1 ; patient 2; -..- 1st day; - 2nd day

\section{Influence of sampling time}

In view of the finding of variability caused by various factors were considered whether a sampling time could be found where fructosamine readings showed little variability. Figure 4 shows fructosamine concentrations measured in sera from 5 Type 1 diabetic patients drawn at three specified times on 2 successive days. The fasting values before insulin were always the low- est, and lunch time values were often the highest. This reflects the course of the protein concentration in diabetic patients (Fig. 5). Again, correcting for the amount of protein decreased the fluctuations, but it did not eliminate them (data not shown).

\section{Discussion}

Our results show that the protein concentration is an important factor which influences fructosamine determination (Figs. 1, 2). This is expected since to concentration of the reducing ketoamine parallels that of protein. The practical importance of the variability of the protein concentration on fructosamine results has either not been recognised [5, 11], or has been considered unimportant by others [12] except in severe hypoalbuminaemia [12-14].

The pronounced variability of the plasma protein concentration in some diabetic patients causes relevant changes in fructosamine concentrations. This is illustrated by the data in Figure 2 in patients A and B. Despite the greatly differing metabolic control of patient A (15 mmol/l glucose; $\left.\mathrm{HbA}_{1 \mathrm{c}} 10.5\right)$ and patient B ( $9.7 \mathrm{mmol} / 1$ glucose; $\mathrm{HbA}_{1 \mathrm{c}} 6.0$ ), fructosamine values in samples with a high protein concentration of patient $\mathrm{B}$ were comparable to those with a low protein concentration of patient A (Fig. 2).

The uncertainty introduced by fluctuations in protein concentration can be estimated if fructosamine values are related to mean blood glucose concentrations. It has been shown that $1 \mathrm{mmol} / 1$ fructosamine in patients in stable control corresponds to an average blood glucose concentration of approximately $7.8 \mathrm{mmol} / 1$ [14]. In diabetic patients a fluctuation of the plasma protein concentration by $20 \mathrm{~g} / 1$ produces a change in fructosamine readings in this order of magnitude. Hence the objective information about averaged glycaemia may be markedly invalidated by the fluctuations in protein concentration.

Correcting for the protein concentration somewhat reduces the variability of fructosamine results (Fig.1, lower panel); the overlap of fructosamine values betwen patient $\mathrm{A}$ in poor and patient $\mathrm{B}$ in satisfactory glycaemic control was eliminated (Table 1 ). It also narrowed the distribution of fructosamine values in normal subjects (Fig. 3).

Non-enzymatic glycosylation of serum proteins has been shown to discriminate well between diabetic patients and control subjects [2,16-18]. In studies with the fructosamine assay and a somewhat different patient selection, serum fructosamine concentrations of diabetic patients and control subjects were not as clearly separated $[11,15]$. Fructosamine values normalised for protein concentration as described narrows their distribution. This correction could improve the discriminatory power of the fructosamine test.

It has been reported that relations between estimates of protein glycation by the fructosamine test and 
other techniques were not made more exact by correcting fructosamine for albumin or serum protein concentration; the separation between normal and diabetic sera was even less when such a correction was applied [5]. It can be concluded from our data that variability of fructosamine results, caused in part by a variable protein concentration, has contributed to these poor correlations.

The excellent relationship between glycated serum protein and glycated albumin [2], and the satisfactory discrimination between normoglycaemic control subjects and diabetic patients based on protein glycation as measured by the thiobarbituric acid colorimetric technique, support this hypothesis $[17,18]$.

The decreased fructosamine values during pregnancy are in agreement with published data [19]. Fructosamine values are decreased in proportion to the decreased plasma protein concentration during pregnancy [20]. Protein corrected fructosamine values are not different from those determined in non-pregnant normal subjects.

When fructosamine concentrations are corrected for protein in plasma of pregnant non-diabetic women the results are comparable to those of control subjects. None of the approaches used to reduce variability in diabetic patients yielded entirely satisfactory results. Though fructosamine concentrations are linearly related with protein concentration, correcting for protein did not eliminate variability. Blood collection at a given time of the day was equally unsatisfactory. Delipidation combined with protein correction also failed to yield frucosamine results which would allow the assessment of intermediate-term glycaemia by fructosamine determinations with the precision required for the quantitative assessment of averaged glycaemic control in diabetic patients.

Delipidation of samples by Aerosil treatment not only removes lipids but also somewhat decreases the protein concentration [10]. Therefore, it seems feasible that a more adaequate procedure for the extraction of the factor(s) causing variability, in combination with correction for the variable protein concentration in the sample, could improve the reliability of the fructosamine test to an acceptable level.

Acknowledgements. The authors thank Dr. S. Heinzel from the Frauenspital Basel for providing blood samples from pregnant women, and Drs. T. Resink and I. Gregor for reviewing the manuscript. This work was supported by grant No.3.420 -0.86 from the Swiss National Science Foundation

\section{References}

1. Mayer TK, Freedman ZR (1983) Protein glycosylation in diabetes mellitus: a review of laboratory measurements and of their clinical utility. Clin Chim Acta 127: 147-184

2. McFarland KF, Catalando EW, Day JF, Thorpe R, Baynes JW (1979) Nonenzymatic glucosylation of serum proteins in diabetes mellitus. Diabetes 28: 1011-1014
3. Schleicher E, Wieland OH (1981) Specific quantitation by HPLC of protein (lysine) bound glucose in human serum albumin and other glycosylated proteins. J Clin Chem Clin Biochem 19: $81-87$

4. Mallia KA, Hermanson GT, Krohn RI, Fujimoto EK, Smith PK (1981) Preparation and use of a boronic acid affinity support for separation and quantitation of glycosylated hemoglobins. Anal Lett 14: 649-661

5. Johnson RN, Metcalf PA, Baker JR (1982) Fructosamine: a new approach to the estimation of serum glycosylprotein: an index of diabetic control. Clin Chem Acta 127:87-95

6. Eadie MJ, Tryrer JH, Kukums JR, Hooper WD (1970) Aspects of tetrazolium salt reduction relevant to quantitative histochemistry. Histochemie 21: 170-180

7. Baker JR, Metcalf PA, Johnson RN, Newan D, Rietz P (1985) Use of protein-based standards in automated colorimetric determinations of fructosamine in serum. Clin Chem 31: 1550-1554

8. Kingsley GR (1939) The determination of serum total protein, albumin and globulin by the Biuret reaction. J Biol Chem 131: 197-200

9. Flückiger R, Woodtli T (1985) Effect of temperature on quantifying glycated (glycosylated) hemoglobin by cation-exchange chromatography. Clin Chem 31: 114-117

10. Agnese ST, Spierto FW, Hannon WH (1983) Evaluation of four reagents for delipidation of serum. Clin Biochem 16: 98-100

11. Baker JR, O'Connor JP, Metcalf PA, Lawson MR, Johnson RN (1983) Clinical usefulness of estimation of serum fructosamine concentration as a screening test for diabetes mellitus. $\mathrm{Br}$ Med 287: 863-867

12. Lloyd D, Marples J (1984) Simple colorimetry of glycated serum protein in a centrifugal analyzer. Clin Chem 30: 1686-1688

13. Hindle EJ, Rostron GM, Gatt JA (1985) The estimation of serum fructosamine: an alternative measurement to glycated haemoglobin. Ann Clin Biochem 22: 84-89

14. Kutter D, Thoma J (1985) Serum-Fruktosamine, ein neuer Parameter zur indirekten Bestimmung des Gluko-Albumins und zur Halblangzeitüberwachung des Diabetikers. Lab Med (Stuttgart) 9: $327-330$

15. Baker JR, Metcalf PA, Holdaway IM, Johnson RN (1985) Serum fructosamine concentration as measure of blood glucose control in type I (insulin dependent) diabetes mellitus. Br Med J 290: 352-355

16. Kennedy AL, Mehl TD, Merimee TJ (1980) Nonenzymatically glycosylated serum protein: spurious elevation due to free glucose in serum Diabetes 29: 413-415

17. Ma A, Naughton MA, Cameron DP (1981) Glycosylated plasma protein: a simple method for the elimination of interference by glucose in its estimation. Clin Chim Acta 115: 111-117

18. Murtiashaw MH, Young JE, Strickland AL, McFarland KF, Thorpe SR, Baynes JW (1983) Measurement of nonenzymatically glucosylated serum protein by an improved thiobarbituric acid assay. Clin Chim Acta 130: 177-187

19. Roberts AB, Court DJ, Henley P, Baker JR, James AG, Ronayne ID (1983) Fructosamine in diabetic pregnancy. Lancet 2: 998-1000

20. Hytten FE, Leitch I (1971) The physiology of human pregnancy, 2nd edn. Blackwell, Oxford, p 47

Received: 23 December 1986

and in revised form: 23 June 1987

Dr. R. Flückiger

Zentrum für Lehre und Forschung

Diabetologie

Hebelstraße 20

CH-4031 Basel

Switzerland 